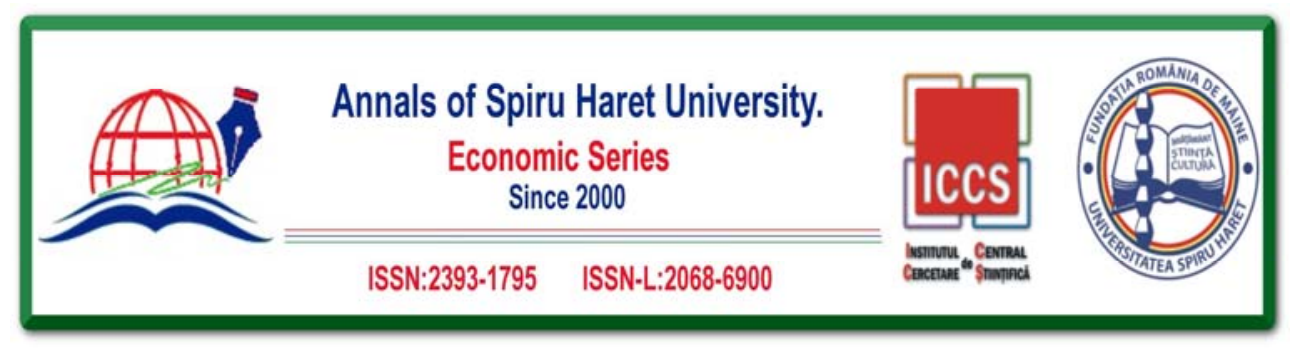

Issue $3 / 2018$

\title{
IMPLEMENTATION OF CORPORATE GOVERNANCE MECHANISMS IN TOURISM
}

\author{
Fuad JABBAROV ${ }^{1}$ \\ ${ }^{1}$ Azerbaijan Tourism and Management University, \\ E-mail: fuadjabbarov@gmail.com
}

How to cite: JABBAROV, F. (2018). "Implementation of Corporate Governance Mechanisms in Tourism." Annals of Spiru Haret University. Economic Series, 18(3), 113-122, doi: https://doi.org/10.26458/1847

\begin{abstract}
The article is devoted to forming of effective mechanisms that regulate economic activity of subjects. The economic state affects activity of companies, especially in tourism. The aim of this paper is to show how implementation of corporate governance mechanisms provides greater transparency in the tourism sector, as well as a higher level of alignment of the domestic regulatory framework with the principles applied in the developed economies in this industry; different internal and external factors affecting the steady evolution and development of companies; currency parity and increase of bank interest rates and their influence on a tourist stream; forming of steady mechanisms by means of implementation of elements and principles of corporate management, possibilities of adaptation and implementation of mechanisms of corporate management.
\end{abstract}

Keywords: corporate governance; consumer basket; economic condition; currency parity; diversification; rate of bank in interest.

\section{JEL Classification: G3}

\section{Introduction}

Governance raises questions about who decides, when, on what. Governance is also related to the institutional capacity to change properly and in timely fashion to the institutional needs. [Bălăceanu, Tilea, \& Predonu, 2010] 
Issue $3 / 2018$

Corporate governance is concerned with the mechanism or organization employed to safeguard the rights of shareholders. The need for corporate governance stems from the problem of agency issue. In a corporate system managers have more power and information than isolated shareholders.

Corporate governance refers to the processes that govern and direct firm managers to come to decisions that are in line with the shareholders' objective of wealth maximization. [Akbar, 2015]

Corporate governance is the set of policies, processes, laws, customs, and institutions which is affecting the way a corporation is administered, directed or controlled. In other case, corporate governance also includes the relationships among the different stakeholders involved and the aims the corporation is governed for. [http://www.iodonline.com/Articles/Corporate\%20Governance\%20and\%20 Sustainability\%20Concepts\%20Sreeti\%20Raut.pdf]

Functioning of corporate governance is analyzed and explained with a use of various theories e.g. agency dilemma or the principal-agent problem and transaction costs theory. It is a fact that, as a rule, the mechanism of corporate governance is generally implemented due to the importance of minimizing the undesirable effects of agency problem. [http://www.ef.umb.sk/konferencie/vdrsp/zb/pdf/Mazurkiewicz.pdf]

It is a fact that, for a sustainable economic growth, the local and regional authorities should identify funding sources to facilitate and encourage long-term investment according to local and regional particularities and considering the challenges faced by business or institutional operators. [Gabroveanu (Vlădoi), \& Ștefănescu, 2017]

However, the objective of this study is to develop a conceptual model by including the factors of corporate governance in the context of tourism, as well as executives of the firms and other stakeholders. The implementation of these kinds of regulatory measures along with the conventional tools will strengthen the corporate governance system which in turn will increase the firm performance in the tourism sector. [Implementing the White Paper on Corporate Governance in Asia, 2006]

Generally, whenever a party has a discretionary possibility to make decisions which affect the interests of other stakeholders, potential conflicts of their interests (the so-called agency problems) arise due to a possibility of that party giving priority to their personal interests over those common. Within the corporate governance context, corporate governance standards may represent a significant factor of growth 


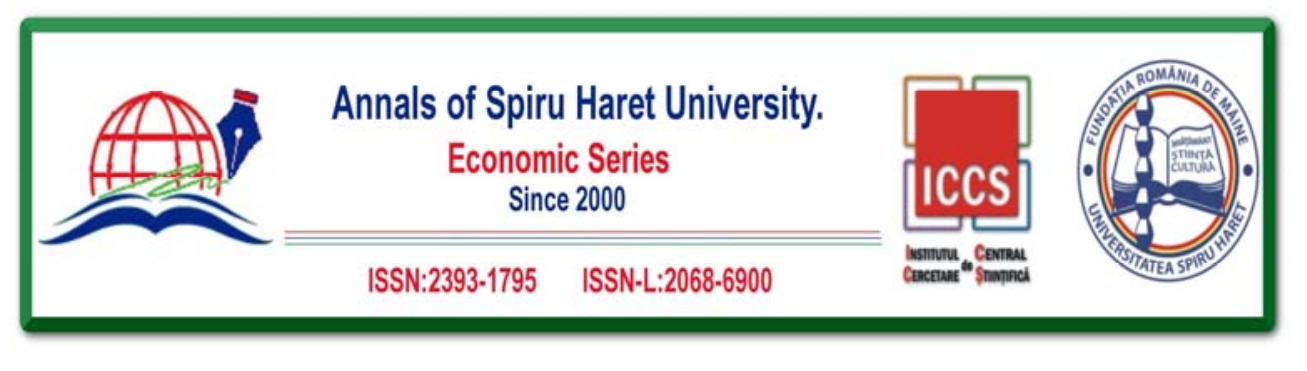

Issue $3 / 2018$

and development of a company, precisely because their implementation should ensure optimum exercise and protection of interests of all stakeholders in its operation.

\section{Research Methodology}

This paper represents a descriptive and analytical case study of the implementation of corporate governance in tourism sector within a real-life context [Creswell, 2014]. The main aim of the theoretical research is to describe or capture lived experiences in the various context. [Yin, 2002; Creswell, 2014] The analytical component of this study involves in-depth study and testing of available information in an attempt to clarify and explain complex phenomena, namely corporate governance in the context of tourism. The descriptive part of this research is focused on discovering new meaning, clarifying what exists, determining the frequency with which something occurs, as well as categorizing information [Selltiz et al., 1976; Burns and Grove, 2005], in order to maintain consistency, for a better comparison, with a critical and independent approach to the subject matter preferable.

\section{Theoretical and Comparative Approaches to the Implementation of Corporate Governance Mechanisms in Tourism}

Before the start of the research, it would be better to pay attention to four considerations to keep in mind when building effective governance structures as in the figure 1 .

Modern market trends in the world, in the process of constant volatility of market conditions, supply and demand, contribute to the development of certain mechanisms to counter the recession. In recent decades, due to the growing demand for tourism services, the states create opportunities for the functioning of enterprises operating in this economic sphere. Solving problems related to the external nature of the impact on economic processes becomes most relevant. The development of an effective mechanism that promotes optimization of structural changes becomes a priority in public policy. In this regard, state agencies work out and devise strategic development plans. In most cases, they are characterized by diversification in state economic policy. [http://siteresources.worldbank.org/EXTPREMNET/Resources/ 489960-1338997241035/Growth_Commission_Working_Paper_21_Export_ Diversification_Economic_Growth.pdf] 


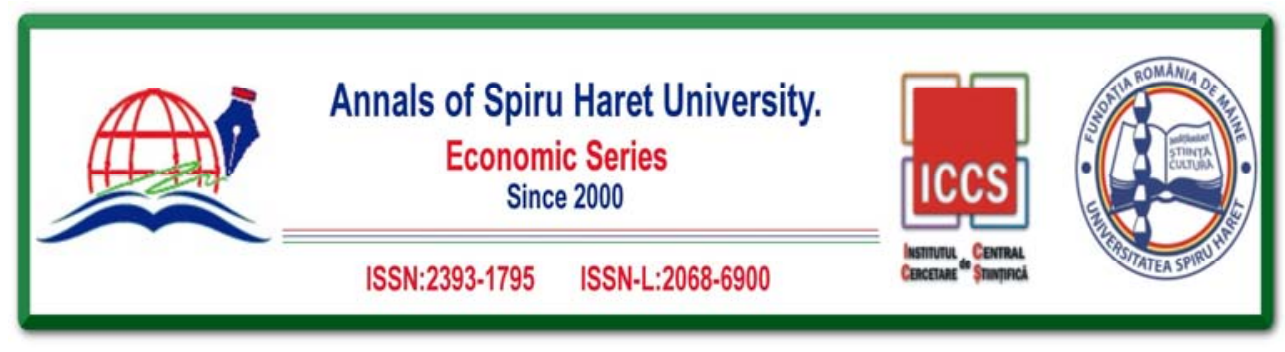

Issue $3 / 2018$

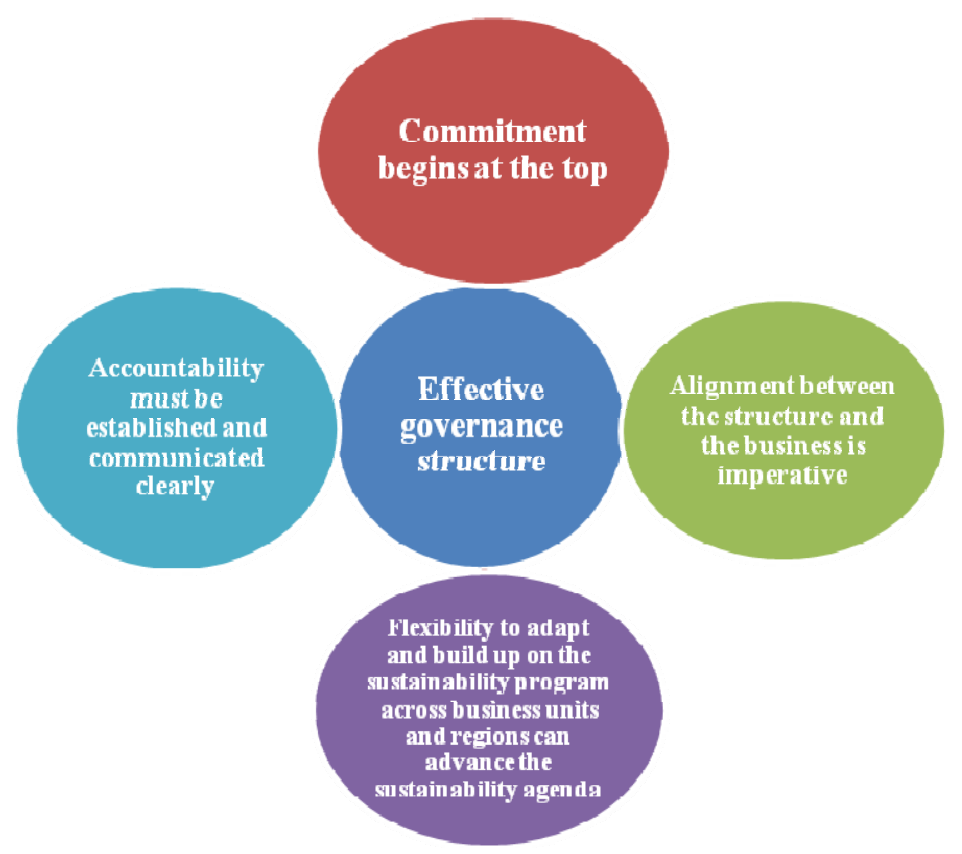

Fig. 1. Consideration when Building an Effective Governance Structure

In connection with these factors, innovation, tourism and the development of intellectual potential are considered to be the top priority sectors of the state investment. Each of them is individually considered to be differentiated and the most priority in the development system, and long-term investments. However, the constant transformation of economic activity forces us to correct the strategic orientation of state policy. Market volatility and budget deficits do not provide an opportunity to implement state priorities in the necessary and time-bound periods. The implementation of large-scale projects with the prospect of a 20 -year payback period and future revenues minimizes the risk of investment. [https://www.leg. state.nv.us/Division/Research/Publications/Bkground/BP83-09.pdf]

Despite such a tendency of the state investment policy on financial investments, there are risks that are not anticipated at the time of the project's creation. In this case, we are talking about currency and inflation risks. Indicators and regulators of the 116 


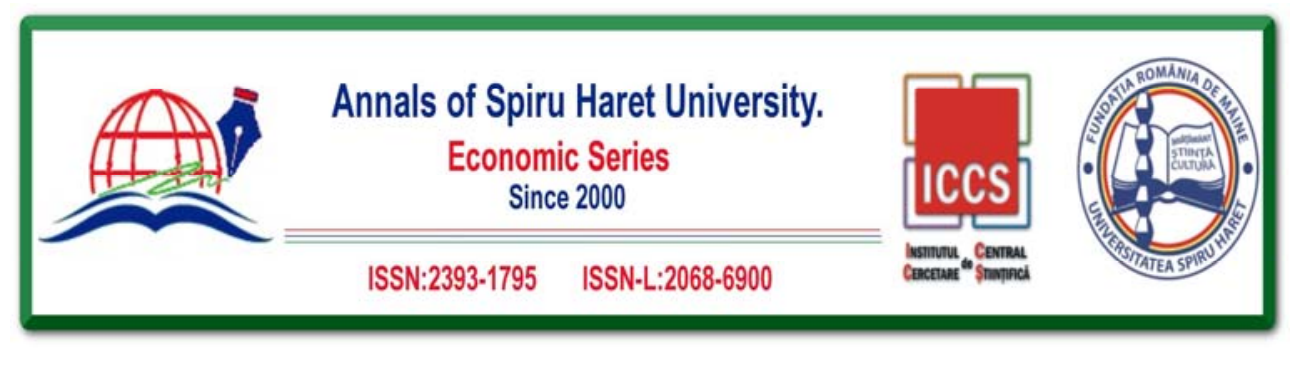

Issue $3 / 2018$

country's economic development are GDP indicators, the number of consumption, employment, trade turnover and industry. At an even level of economic development, there is no imbalance in currency parity and inflation. Otherwise, a different kind of imbalance in the correlation between the level of inflation and the negative exchange rate difference in the currency occurs naturally. [European Journal of Sustainable Development, 2017] The reasons that caused this imbalance can be the external trade balance, a decrease in the speed of money supply turnover, monopolization and low solvency of the population. Due to the above reasons, the current economic imbalance negatively affects the economic indicators. There is a whole complex of questions about the need to regulate and adjust economic processes.

Let's consider the reasons that caused the imbalance separately in order to draw the necessary conclusions. The external trade balance is the main indicator of the ratio of local currency to freely convertible currency (FCC). The ratio of the exchange rate also has various cause-and-effect factors. The stability of the currency parity of the Azerbaijani Manat (AZN) was provided by high prices for energy resources. After the fall in oil prices, the local currency devalued against others. Based on the theory of currency parity, the model proposed by Mundell and Fleming is interpreted as an increase in domestic consumption, as well as the creation of the final product and its exports despite the negative importance of the ratio of currencies in the international trade balance, the main article of which is the export of raw materials. The second reason is a decrease in the speed of money supply turnover, which is connected, first of all, with the indices of industrial development. [Viner, 1971] Low indices of industrial development in Azerbaijan cannot affect the stability of the Azerbaijani Manat (AZN). The consequence of this factor is the monopolistic development of the industry, which does not take into account the price range and the premium in the formation of the final price or the value of the commodity oriented to the local market. Lack of competition in the local market leads to an excess of goods, the implementation of which creates certain problems, so companies are trying to sell it in foreign markets at a low price, but for a hard currency. And, the last reason is the low solvency of the population, caused by a number of factors. First, the level of the consumer basket, which must correspond to the existing prices on the market and is constantly indexed to ensure economic circulation. Secondly, the level of employment of the population and the poverty line. In connection with the suspension of various economic projects and high seasonal workers, the consumption index is constantly 


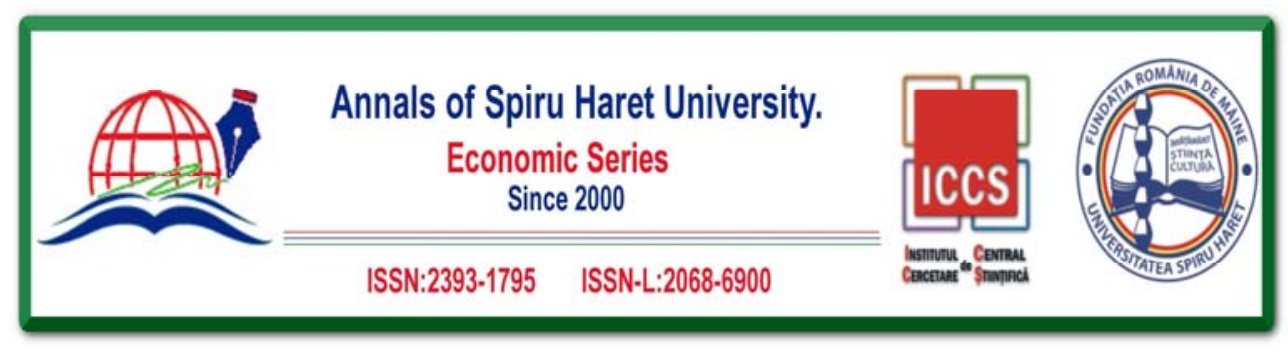

Issue $3 / 2018$

decreasing. The average salary in Azerbaijan varies between 350-524.7 Manats (AZN) according to official statistics, and the minimum wage level is set at 130 Manats (AZN). [http://www.stat.gov.az/source/tourism/\#] With this proportion and taking into account the fact that in the consumer basket the bulk of money is spent on food and public utilities and accounts for about $75 \%$ of the total amount of consumption, commodity turnover cannot show good results.

Due to this scenario and the increase in the unemployment rate, a natural factor is a violation of the economic cycle. In the banking sector, due to these reasons, there is an increase in unpaid consumer loans. Deferred payments and high bank interest create a situation in which retail indicators demonstrate regression. In this case, we are talking about the consumption figures of the local population. Correction and high indicators are explainable from the point of view of the high tourist flow, which, in the economic state and analysis, should not be taken into account. In fact, the economic situation should stimulate industries such as tourism and innovation, but in this sector there are short-term trends caused by spontaneous tourist inflow through state regulation and providing a simplified visa regime for tourists. The tourist infrastructure, which provides a stable influx of tourists, is not effective due to a number of reasons. The fixed level of tourist flow is growing in an unnatural way. The basis of the tourist flow is the implementation of the state program for the diversification of economic development. Hotels that form the basis of tourism infrastructure cannot form and devise a development strategy.

The price range of hotels varies from 80 to 150 AZN (Manat), which naturally affects the number of rooms. Over the past five years, the increased tourist flow was formed by international events. In the last year, the influx of tourists increased due to the countries of the Persian Gulf and Iran. It should be noted that the increase in tourist flow is of a short-term nature and, if the necessary measures are not taken, it will be very difficult to increase this flow in the future. The modern infrastructure of tourism, established in Azerbaijan, cannot function in full force.

There are errors in the approaches and management of modern hotel complexes. International network representations of leading hotels in the world are represented mainly not in the form of direct management, but through a franchise. Compliance with the necessary measures and standards required by the franchise agreement does not provide a basis for management effectiveness. [https:/www.sec.gov/Archives/ edgar/data/853665/000092290705000240/form10kexhf_032905.htm] Hotel managers make many mistakes and are not focused on satisfying domestic demand. Analyzing 118 


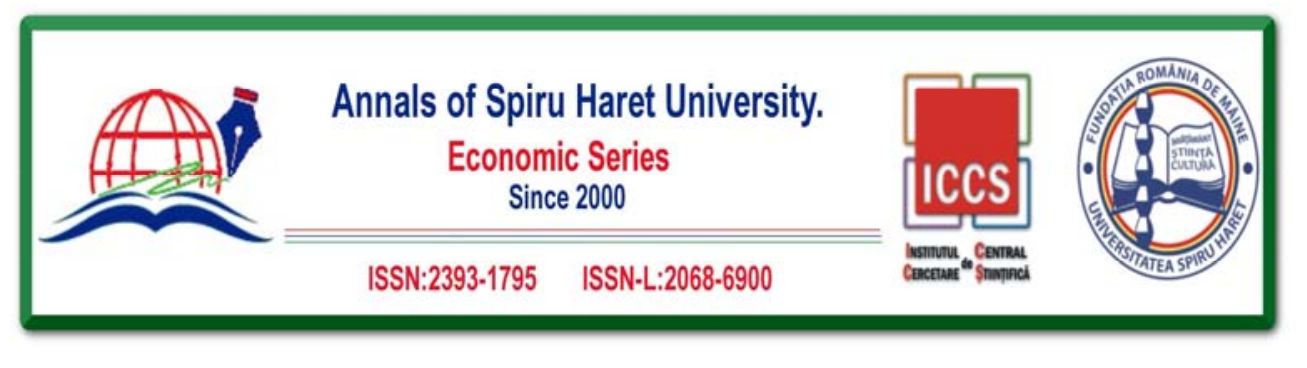

Issue $3 / 2018$

the statistical data, I came to the conclusion that the number of tourists leaving Azerbaijan is greater than the number of visitors.

This analysis makes it possible to conclude that the price policy does not allow citizens of the country to spend their holidays in the country. Basically, a large tourist flow is directed to Georgia and Turkey. This situation creates an opportunity for the formation of mechanisms for the management and regulation of business in this area.

In order to improve the effectiveness of management structures and mechanisms, there is an urgent need to recruit and train professional staff. To this end, the preferential relationship in the choice of the formation of personnel policy should be the organization's own mechanisms in the absence of personnel training. Despite the increase in costs associated with staff training, companies receive benefits in the event of a shortage of specialized training centres.

Such a problem exists in Azerbaijan, and the leakage of personnel capacity is carried out from most hotel complexes, except for the Hyatt Regency, which has its own training centre. Its former employees are the basis of the staff potential of other hotels. The lack of professional staff and the satisfaction of the demand for human resources provide an opportunity for business interaction between a specialized educational institution - in this case the Azerbaijan University of Tourism and Management - and the commercial structures, i.e. tourist enterprises. In spite of partial satisfaction of market demand, the objective is the lack of laboratories in the training of personnel. In particular, the lack of specialized classes in the restaurant business, training bartenders, waiters and other professions requires additional costs. In addition to this reason, there are others related primarily to the availability of intellectual potential. In this connection, the process of reforming the education system and building the personnel capacity for training personnel is actualized. The use of different teaching methods by alternating theoretical skills with practical application is a fundamental requirement of the market and its demand. In this case, the level of intellectual development is formed directly by specialized institutions, capable of satisfying various market demands. From the point of view of economic expediency, delegation of authority to these structures is most beneficial, since the level of expenses incurred cannot be correlated with the own expenses of the organization itself.

Priorities for the development of the innovative industry are beneficial both to the state and business structures. The search and creation of various technologies in a 


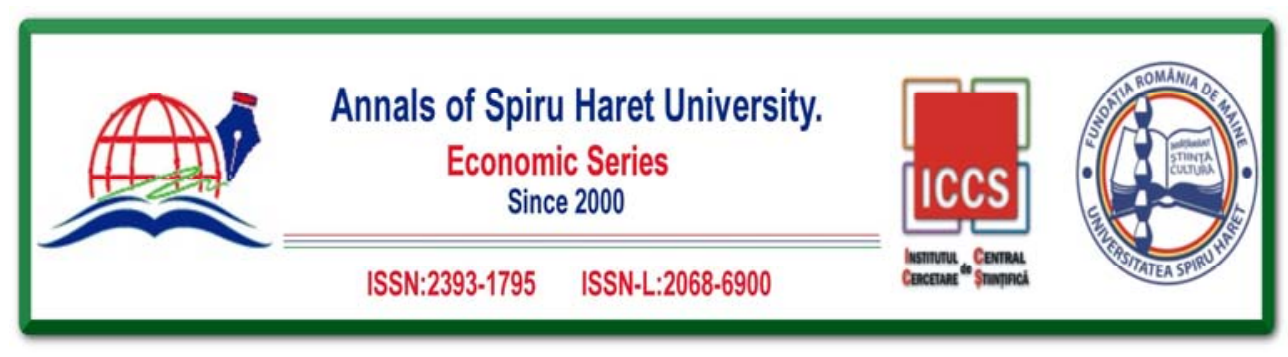

Issue $3 / 2018$

market competition is the most optimal method capable of strengthening leadership positions. The prerogative of public policy in this area is the fundamental areas of research. Budget expenditures will quickly accumulate through the implementation of these technologies by business. Business structures need the creation of research departments to develop new types of goods that can compete in the world market. The creation of new products will strengthen not only market positions, but also create prerequisites for sustainable development. The lack of a strategy to create innovative products will not provide an opportunity to consolidate not only the market position, but also significantly increase the company's expenses for the formation and consolidation of the brand. Market levers of pressure on competitors will face different barriers and resistance to expand the market share from the sustainable brand companies. In this regard, the formation of innovation is an important factor in the company's advantages in the market.

Recently, the most optimal management methods in the sphere of tourism are the implemented mechanisms of corporate governance. They are the most stable forms for changing market conditions due to the volatility of the market itself. However, it should be noted that the adaptation of methods and mechanisms of corporate governance involves a number of problems. [https://www.oecd.org/daf/ca/CorporateGovernance-Principles-ENG.pdf] The functioning of these mechanisms requires the adaptation of the principles and forms of corporate governance. The interconnection of these principles does not allow for their implementation separately. Given the monopolization of the market, their actual applicability of principles meets deformed perception.

However, the owners of companies miss the benefits of the use of corporate governance mechanisms in the operating environment of the organization. In order to eliminate equivocation, it is not necessary to duplicate the same corporate governance departments of different models. For example, the main governing body of corporate governance in the Anglo-American model is the Board of Directors, and in the German model - the Supervisory Board, whose functional purpose is identical. In some cases, local companies adapt both departments to management, which naturally creates an equivocation of the management of the organization. [Jensen \& Meckling, 1976]

\section{Conclusion}

At the end of this study, it seems clear that corporate governance mechanisms primarily support the process of efficient, equal and transparent exercise of the 120 


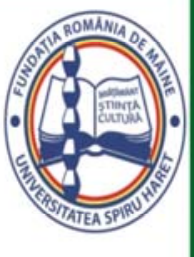

Issue $3 / 2018$

fundamental rights of shareholders such as right to govern or direct a company, right to a share in the distribution of net profit and right to a share in liquidation assets.

The development of importance and promotion of corporate governance coincides with the development of tourism market economy and financial markets. Comparative analysis showed that corporate governance helps reduce various types of risk that may affect the functioning of a company.

Research confirmed that adaptation of corporate governance mechanisms does not depend on the size and segment of the functioning of companies. The implementation of administrative structures can be carried out even in small and medium-sized tourist enterprises. This significantly increases management efficiency and increases the company's profits. In this case, it should be noted that, as a result, the company receives a double benefit: on the one hand, it is the strengthening of the financial situation and economic benefits, on the other, an effective management organization.

With the purpose to improve the efficiency of tourism organizations, structural changes, in particular the reorganization of management structures, need to be carried out. Despite resistance to organizational changes by personnel, the inventory of these processes will lead to a comprehensive increase in the effectiveness of the organization itself. Summarizing the above, I recommend the following measures:

$\checkmark$ Reorganize management in companies;

$\checkmark$ Implement the principles of corporate governance in order to improve the efficiency of the production process;

$\checkmark$ Adapt corporate governance mechanisms to reduce risk and increase profits;

$\checkmark$ Improve the quality of enterprises;

$\checkmark$ Introduce corporate cultures and values in the organization.

\section{References}

1. Akbar, Ahsan (2015). "The Role of Corporate Governance Mechanism in Optimizing Firm Performance: A Conceptual Model for Corporate Sector of Pakistan." Journal of Asian Business Strategy, Volume 5, Issue 6, pp. 109-115.

2. Burns, N., \& Grove, K. The Practice of Nursing Research: Conduct, Critique, and Utilization, St Louis, Mo.: Elsevier/Saunders, 2005.

3. Creswell, J. W. Research Design: Qualitative, Quantitative and Mixed Methods Approaches, 3rd ed., London: Sage, 2014. 


\section{Issue $\mathbf{3} / 2018$}

4. Bălăceanu, Cristina, Tilea, Doina, \& Predonu, Andreea Monica (2010). Practice of Good Governance and Corporate Governance, Annals of Spiru Haret University, Economic Series, 10(1), pp. 69-74.

5. European Journal of Sustainable Development (2017), 6, 4, pp. 329-340.

6. Filatotchev, Igor, Developing an Organizational Theory of Corporate Governance: Comments on Henry L. Tosi, Jr. (2008), "Suggestions for Future Corporate Governance Research”, 21 May 2008, Springer Science+Business Media, LLC. 2008, J Manage Gov.

7. Gabroveanu (Vlădoi), Janina Mirela, \& Ștefănescu, Alexandru (2017). "The Role and Involvement of Business and Institutional Operators in Promoting Local Investment and Economic Growth by Accessing and Using Grants. Measures and Courses of Action." Annals of Spiru Haret University, Economic Series, 17(1), 2017, pp. 57-71.

8. Organisation for Economic Co-operation and Development, Implementing the White Paper on Corporate Governance in Asia, October 2006, p. 20.

9. Jensen, M., \& Meckling, W. (1976). "Theory of the Firm: Managerial Behavior, Agency Costs and Ownership Structure.” Journal of Financial Economics, Vol. 3, pp. 305-360.

10. Selltiz, C., Wrightsman, L., \& Cook, S. Research Methods in Social Relations, New York, 1976.

11. Viner, J. Problems of Monetary Policy in the 1970s. Oxford, 1971, p. 245.

12. Yin, K. Applications of Case Study Research, London: SAGE Publishers, 2002.

13. https://www.oecd.org/daf/ca/Corporate-Governance-Principles-ENG.pdf_

14. https://www.sec.gov/Archives/edgar/data/853665/000092290705000240/form10kexhf_ 032905.htm

15. http://www.stat.gov.az/source/tourism/\#

16. http://siteresources.worldbank.org/EXTPREMNET/Resources/489960-1338997241035/ Growth_Commission_Working_Paper_21_Export_Diversification_Economic_Growth. pdf

17. https://www.leg.state.nv.us/Division/Research/Publications/Bkground/BP83-09.pdf 